\title{
Determinants of Indivdual's Investment Decision in Islamic Banking: A Case Study from Vehari
}

\author{
Allah Ditta ${ }^{1}$, Khuda Bakhsh ${ }^{2}$ \\ ${ }^{1}$ Department of Economics, Virtual Campus, COMSATS Institute of Information \\ Technology, Vehari-Pakistan \\ ${ }^{2}$ Department of Management Sciences, COMSATS Institute of Information Technology, \\ Vehari, Pakistan
}

\begin{abstract}
There are two types of banking systems functioning in Pakistan. They include conventional and Islamic banking systems. Individuals take decisions to invest in a particular banking system while considering socioeconomic, religious and psychological factors. The present study is designed to examine factors affecting individual's investment decision in Islamic banking. The study uses cross-sectional data collected from Vehari district of the Punjab province. A total of 150 respondents were selected randomly having accounts or availing any other type of banking facility from conventional and Islamic banking. We used a 5 point Likert scale for getting information on customer satisfaction. The study considers social, religious and psychological factors having influence on individual's investment decision. Logit model was employed to determine factors affecting the decision of individuals in making investment in a specific banking system. The study provides insights on factors inducing individuals to make investment in a particular type of banking system. Age and education of respondents, whether banking is according to Islamic principles, ethical responsibility, wide range of Islamic products and networks are statistically related factors affecting decision on making investment in Islamic or conventional banks. Results of the study are useful for concerned banks to attract individuals to purchase the products.
\end{abstract}

\section{Introduction}

Banking sector is considered an integral part of the economic growth of any country. Banks provide a wide range of services to customers. People make investment in banks' products in order to maximize profit. Choice of investing in a bank depends on different factors. They include social, economic, religious and psychological factors, in addition to bank's working environment. Eastlick (1996) shows that people go through a decision making process consisting of problem recognition, information search,

Corresponding Author: Khuda Bakhsh, e-mail: kbakhsh@ciitvehari.edu.pk

o COMSATS Institute of Information Technology Lahore, Pakistan. 
valuation of alternative purchase decision and post purchase behaviors. Mittal and Vyas (2008) provide empirical evidence relating to factors affecting investment decision in banks. They include income, education, gender, marital status, occupation, and cultural background. Further, type of banks matters in making an investment decision.

There are two types of banking systems in Pakistan. They include conventional and Islamic banking systems. Many conventional banks have devoted Islamic windows/branches solely dealing in Islamic banking whereas some banks only deal in Islamic banking. Religion is an important factor for making investment in an Islamic bank (Ahmad and Haroon, 2002, Dusuki and Abdullah, 2006, Osman et al., 2009, Alam et al., 2011). As Islamic banks have competition with conventional banks in Pakistan, Islamic banks provide better customer services to attract customers as indicated by (Dusuki and Abdullah, (2006). Gait and Worthington (2008) conclude that service quality, bank reputation, religious and pricing aspects are also important in making investment decisions. Al-Ajmi et al. (2009) shows that economic and bank related factors influence investment decision in Bahrain.

There are different factors affecting investment decision either in Islamic or conventional banks. Such factors include social, economic, religious, psychological and cultural factors. Although studies are available on efficiency analysis of Islamic vs. conventional banks in Pakistan, we find no study in the literature on factors affecting investment decision of individuals. The need is to identify factors affecting investment in Islamic banks. The present study contributes in the literature as it provides empirical evidence from Pakistan on factors affecting investment decision in Islamic and or/conventional banks. So the present study fills the existing gap on this issue in Pakistan. Findings of the study provide insights to develop policy guidelines for attracting more investors to Islamic banks.

The present research article is divided into five sections. The first section is introductory. Type and source of data and empirical methods are discussed in the second section. Third section describes results and discussion followed by the conclusion. The last section is devoted to references.

\section{Methodology}

The present study is limited to Vehari district of Pakistan due to financial constraints. Vehari is situated in Southern Punjab. It is a fast developing district of the province with the advent of the top ranked universities, in addition to high agricultural productivity and emerging business activities. Different public and private banks operate in the district. Like other districts of Pakistan, conventional and Islamic banking is also available. Some banks solely deals, in Islamic banking while some have devoted an Islamic window to provide services to customers. 
We selected one bank dealing only in Islamic banking (Meezan Bank) and one conventional bank i.e. Bank Al-Habib. Both Meezan and Al-Habib are private banks. We obtained the list of customers from different branches of Meezan Bank and Bank-Al Habib. A total of 150 respondents were selected from the list using simple random sampling technique. A pre-tested and well-structured questionnaire was used to collect information on factors affecting investment decisions by customers. We got the questionnaires filled employing personal interview method.

Our sample included both male and female respondents. Out of 150 respondents, $15 \%$ were female and $85 \%$ were male respondents. Majority of the respondents have education level above matriculation. Details of variables along with summary statistics have been given in Table 1 .

Table 1. Summary statistics of variables

\begin{tabular}{|l|c|c|}
\hline \multicolumn{1}{|c|}{ VARIABLES } & Mean & Standard deviation \\
\hline Demographic factors & 0.85 & 0.36 \\
Gender & & \\
Education (\%) & 6.00 & \\
Matriculation & 46.67 & \\
Intermediate & 47.33 & \\
Graduation and above & & \\
Bank related factors & 3.15 & 1.30 \\
Banking according to Islam & 3.39 & 1.18 \\
Modern look of Islamic bank & 3.23 & 1.18 \\
Friendly attitude of employees & & 1.24 \\
Religious factors & 3.85 & 1.17 \\
Religious obligation & 3.50 & 1.13 \\
Ethical responsibility & & 1.09 \\
Psychological factors & 3.37 & 1.18 \\
Mudraba (profit/loss) & 3.39 & \\
Range of Islamic products & 2.96 & \\
Social factors & & \\
Family and friends & & \\
\hline
\end{tabular}

2.1 Rational choice theory and individual decision relating to investment in bank Every individual in a society makes decisions and final decision-making emerges as a result of influence of different factors. Economic models are helpful in understanding the decision-making process and factors having impact on the process. Rational choice 
theory guides us to understand the decision-making process and individual behavior. The focus of the theory is, therefore, the determinants of individual choices. This theory assumes that individuals have clear information relating to the problem, constant and clear preferences, options or choices are known to individuals and individuals are interested in maximizing utility. Based on this theory, the present study is designed to examine the decision-making process of individuals while investing in Islamic and or conventional banks. In the present study, choices of investing in either type of banks is well known and clear to the individuals. Individuals are assumed to be utility maximizers and their decision of investing in either bank depends on various factors including location, religion, social and psychological factors. The present study hypothesizes that these factors are not related with decision-making process of individuals while investing in Islamic or conventional banking system.

\subsection{Empirical methods}

Descriptive statistics has been used to compare factors affecting investment decision. They include frequency, percentage and mean. Econometric method i.e. logit model has been used to examine different factors have impact on individual decision relating to investment either in Meezan or Al-Habib bank. We consider value of dependent variable as one indicating individual making investment in Meezan Bank and zero for those individuals who have accounts or invested in Al-Habib Bank. Logit model can be written as

$$
\begin{aligned}
& P_{i}=\operatorname{Prob}\left(Y_{i}=1\right)=F\left(b^{\prime} X_{i}\right)=\frac{1}{1+e^{-z_{i}}} \\
& \ln \left[\frac{P_{i}}{1-P_{i}}\right]=\ddot{X}_{i}
\end{aligned}
$$

where $Y_{i}$ shows the observed response for the $\mathrm{i}$-th observation. It implies that $Y_{i}$ is equal to one for the respondent investing in Meezan Bank and $Y_{i}$ is zero when an individual makes investment in Al-Habib Bank. $X_{i}$ is a set of independent variables. The odd ratio is given by $\left.\frac{P_{i}}{\left[1-P_{i}\right.}\right]$ showing the ratio of presence of the outcome to the non-presence of the outcome. When we take $\log$ of the odd ratio, it gives us a logit i.e. $Z_{i} . Z_{i}$ has a value between negative and positive infinity and it is a linear function of independent variables. The following logit model has been employed in the present study:

$$
Z_{i}=\beta_{o}+\Sigma \beta_{i} X_{i}+\mu
$$

$\beta_{o}$ and $\beta$ are constant and change in logit as a result of change in independent variables, respectively. As we want to estimate probability with a one unit change in 
explanatory variables, it can be estimated as

$$
\frac{P_{P}}{\partial X_{i}}=b_{i}\left[P_{i}\left(1-P_{i}\right)\right]
$$

Explanatory variables used in the logit model include demographic, bank related, religious, psychological and social factors. We considered two demographic factors namely gender (dummy variable, one for male and zero else) and education (value from one to three, one indicates education level by matriculation, two represents intermediate and three is used for graduation and above). Bank related factors are "whether Islamic banking is as per Islamic laws", "Islamic banks have modern infrastructure and facilities" and "friendly environment of employees of Islamic bank". Religion has an important part in inducing individuals to invest in Islamic banks. So we considered religious obligations and ethical responsibility factors. Profit/loss on Mudraba principle and a wide range of Islamic products are factors considered as psychological factors whereas recommendation by family and relatives is taken as the social factor. Except for a demographic factors, we used Likert scale in the analysis. Likert scale ranges from one to five (strongly disagree, disagree, neutral, agree, and strongly agree).

\section{Results and Discussion}

We consider various factors affecting individuals' decision about making investment or having account in Islamic bank. Logit model has been employed to examine these has been determinants. Results are given in Table 2. Demographic factors considered in the present study are statistically different from zero. Probability of having account or investment in Islamic bank would increase by 0.935 percent if the respondent is male. The reason lies in the fact that if an Islamic bank is at some distance from home, males are more probable to have an account compared to females whose movement is very limited in the context of social conditions in Vehari. Further, males are mostly decisionmakers in households. Another demographic variable is education level of the respondents. This variable has values increasing from low to high (matriculation to graduation and above). An increase in education level of the respondents is found to be increasing probability of having investment in Islamic bank by 0.804 percent. With increased education level, respondents have access to information and therefore, they may be in a better position to decide while making investment in any type of banking system.

Characteristics of any type of bank are important to induce individuals for their decisions. Close proximity and other related factors are important. In the present study, we asked the respondents whether banking is purely Islamic using Likert scale. Results 
show that the factor "banking according to Islam" has a positive and significant impact on individuals' decisions. When the score increases by one point, it would increase probability of making decision in favor of Islamic bank by 0.568 percent. It implies that people would invest in Islamic banks if they are sure that Islamic bank purely works on Islamic principles. Another bank related factor i.e. infrastructure or modern outlook of bank is not related with individuals' decision as the coefficient is statistically nonsignificant.

Religion related factors are the most important factors having impact on the decisionmaking process relating to investment. Religious obligation and ethical responsibility are considered in the present study. Respondents were asked to provide information whether investing in Islamic bank is a religious obligation. This variable is statistically non-significant, although the sign is according to a priori expectation. Another variable is ethical responsibility and it is found statistically different from zero along with positive sign. It implies that with increasing score of this variable, probability of making decision in favor of Islamic bank would increase by 0.829 percent.

We also considered psychological factors in influencing decisions of individuals. Out of the two variables, only one variable is statistically significant and its coefficient is positive. Wide range of bank products has positive impact on making decisions relating to investing in Islamic bank. Increasing score of this variable would increase probability in favor of Islamic bank by 1.209 percent. This implies that people prefer to invest in any bank if they come to know that there are a number of products considering their daily needs.

One social factor "recommendation by family and friends" is statistically significant and positive. An increase in score of this variable would increase probability of making decision in favor of an Islamic bank by 0.558 percent. The result implies that family and social networks play an important role in decision-making process of individuals. 
Table 2. Estimates of Logit model

\begin{tabular}{|c|c|c|}
\hline VARIABLES & Coefficients & Marginal effects \\
\hline \multicolumn{3}{|l|}{ Demographic factors } \\
\hline Gender & $\begin{array}{c}2.129^{* * *} \\
(0.655)\end{array}$ & $\begin{array}{l}0.935^{\star * *} \\
(0.313)\end{array}$ \\
\hline Education & $\begin{array}{l}0.642^{*} \\
(0.347)\end{array}$ & $\begin{array}{l}0.804^{*} \\
(0.441)\end{array}$ \\
\hline \multicolumn{3}{|l|}{ Bank related factors } \\
\hline Banking according to Islam & $\begin{array}{l}0.347^{* *} \\
(0.173)\end{array}$ & $\begin{array}{l}0.568^{* *} \\
(0.291)\end{array}$ \\
\hline Modern looking of Islamic bank & $\begin{array}{l}-0.187 \\
(0.248)\end{array}$ & $\begin{array}{l}-0.329 \\
(0.439)\end{array}$ \\
\hline \multicolumn{3}{|l|}{ Religious factors } \\
\hline Religious obligation & $\begin{array}{c}0.371 \\
(0.230)\end{array}$ & $\begin{array}{c}0.742 \\
(0.474)\end{array}$ \\
\hline Ethical responsibility & $\begin{array}{l}0.457^{* *} \\
(0.212)\end{array}$ & $\begin{array}{l}0.829^{* *} \\
(0.393)\end{array}$ \\
\hline \multicolumn{3}{|l|}{ Psychological factors } \\
\hline Mudaraba (profit/loss) & $\begin{array}{l}-0.254 \\
(0.221)\end{array}$ & $\begin{array}{l}-0.444 \\
(0.390)\end{array}$ \\
\hline Range of Islamic products & $\begin{array}{l}0.687^{* * *} \\
(0.244)\end{array}$ & $\begin{array}{l}1.209^{* * *} \\
(0.448)\end{array}$ \\
\hline \multicolumn{3}{|l|}{ Social factors } \\
\hline Family and friends & $\begin{array}{l}0.363^{*} \\
(0.190)\end{array}$ & $\begin{array}{l}0.558^{*} \\
(0.297)\end{array}$ \\
\hline Friendly attitude of employees & $\begin{array}{l}-0.388 \\
(0.207)\end{array}$ & $\begin{array}{l}-0.649 \\
(0.353)\end{array}$ \\
\hline Constant & $\begin{array}{c}-8.215^{* * *} \\
(1.647)\end{array}$ & \\
\hline Observations & 150 & \\
\hline
\end{tabular}

Standard errors in parentheses

${ }^{* * *} \mathrm{p}<0.01,{ }^{* *} \mathrm{p}<0.05,{ }^{*} \mathrm{p}<0.1$

4. Limitations of the study

The present study has not considered other issues such as type and purpose of depositors, and whether the depositor was a borrower or not. Similarly, financial 
literacy and understanding of the role of marketing on decision making process are also important factors. However, the present study lacks information on these aspects. The future study should be designed to address these limitations in order to deeply examine the impact of different factors on decision-making process.

\section{Conclusion}

Individuals' decisions on making investment in a particular bank are a function of demographic, social, religious and psychological factors. The present study was designed to examine this relationship. Awareness and knowledge of individuals are important in making investment decision as the variable education is statistically significant. Thus targeting educated individuals by Islamic bank would be a fruitful strategy. Family and social networks are considered important factors in dissemination and adoption of new product/technology. This variable is also significant in the present study. So the concerned banks should use networks to influence individuals' decisions in their favor. Increasing range of products by Islamic bank can further impact decisions by potential customers in favor of Islamic bank. Individuals prefer to have an account in a bank with a number of facilities available to them under one umbrella. So the range of products provided by Islamic bank should be equal to conventional banks if it is not larger.

\section{References}

Ahmad, N., \& Haron, S. (2002). Perceptions of Malaysian corporate customers towards Islamic banking products and services. International Journal of Islamic Financial Services, 2(4), 1329.

Al-Ajmi, J., Al-Saleh, N., \& Hussain, H. A. (2009). Clients of conventional and Islamic banks in Bahrain: How they choose which bank to patronize. International Journal of Social Economics, 36(11), 1086-1112.

Alam, S.S., Mohd, R., \& Hisham, B. (2011). Is religiosity an important determinant on Muslim consumer behavior in Malaysia? Journal of Islamic Marketing, 2(1), 83-96.

Dusuki, A.W., \& Abdullah, N.I. (2006). Why do Malaysian customers patronize Islamic banks. International Journal of Banking Markets, 25(3), 142-160.

Eastlick, M.A. (1996). Consumer Intention to adopt Interactive teleshopping, marketing science institute. Working Paper Report, 96-113. Cambridge, M. A. Marketing Science Institute.

Gait, A. \& Worthington, A. (2008). An empirical survey of individual consumer, business firm and financial institution attitudes towards Islamic. International Journal of Social Economics, 35(11), 783-808.

Mittal, M., \& Vyas, R.K. (2008). Personality type and investment choice: an empirical study. The ICFAI University Journal of Behavioral Finance, 5(3), 6- 22.

Osman, I., Ali, H., Zainuddin, A., Rashid, W.E.W., \& Jusoff, K. (2009). Customers' satisfaction in Malaysian Islamic banking. International Journal of Economics and Finance, 1(1), 197-202. 